\title{
$\beta 4$ Tubulin Identifies a Primitive Cell Source for Oligodendrocytes in the Mammalian Brain
}

\author{
Chuanshen Wu, ${ }^{1}$ Ansi Chang, ${ }^{1}$ Maria C. Smith, ${ }^{1,4}$ Roy Won, ${ }^{1}$ Xinghua Yin, ${ }^{1}$ Susan M. Staugaitis, ${ }^{1,2}$ Dimitri Agamanolis, ${ }^{3}$ \\ Grahame J. Kidd, ${ }^{1}$ Robert H. Miller, ${ }^{4}$ and Bruce D. Trapp ${ }^{1}$ \\ Departments of ${ }^{1}$ Neurosciences, Lerner Research Institute and ${ }^{2}$ Anatomic Pathology, Cleveland Clinic, Cleveland, Ohio 44195, ${ }^{3}$ Department of Pathology, \\ Akron Children's Hospital, Akron, Ohio 44308, and ${ }^{4}$ Department of Neurosciences, Case Western Reserve University School of Medicine, Cleveland, Ohio \\ 44106
}

We have identified a novel population of cells in the subventricular zone (SVZ) of the mammalian brain that expresses $\beta 4$ tubulin ( $\beta$ T4) and has properties of primitive neuroectodermal cells. $\beta$ T4 cells are scattered throughout the SVZ of the lateral ventricles in adult human brain and are significantly increased in the SVZs bordering demyelinated white matter in multiple sclerosis brains. In human fetal brain, $\beta \mathrm{T} 4$ cell densities peak during the latter stages of gliogenesis, which occurs in the SVZ of the lateral ventricles. $\beta$ T4 cells represent $<2 \%$ of the cells present in neurospheres generated from postnatal rat brain but $>95 \%$ of cells in neurospheres treated with the anti-mitotic agent Ara C. $\beta$ T4 cells produce oligodendrocytes, neurons, and astrocytes in vitro. We compared the myelinating potential of $\beta$ T4positive cells with A2B5-positive oligodendrocyte progenitor cells after transplantation (25,000 cells) into postnatal day 3 (P3) myelindeficient rat brains. At P20, the progeny of $\beta$ T4 cells myelinated up to $4 \mathrm{~mm}$ of the external capsule, which significantly exceeded that of transplanted A2B5-positive progenitor cells. Such extensive and rapid mature CNS cell generation by a relatively small number of transplanted cells provides in vivo support for the therapeutic potential of $\beta$ T 4 cells. We propose that $\beta$ T4 cells are an endogenous cell source that can be recruited to promote neural repair in the adult telencephalon.

\section{Introduction}

Strategies for cell replacement represent a promising direction for the treatment of neurodegenerative diseases. The best example of CNS cell replacement and repair is the generation of myelinating oligodendrocytes in lesions of multiple sclerosis (MS). Unfortunately, many MS lesions do not remyelinate. Myelin repair requires the generation of new oligodendrocytes from oligodendrocyte progenitor cells (OPCs). OPCs are present in MS lesions (Wolswijk, 1998; Lucchinetti et al., 1999; Chang et al., 2000; Wilson et al., 2006), and some chronic MS lesions contain a limited number of new oligodendrocytes (Chang et al., 2002). OPC proliferation, however, is limited (Temple and Raff, 1986; Barres and Raff, 1994). Primitive cell populations located in the subventricular zone (SVZ) of the lateral ventricles are capable of producing transient amplifying cells that can generate significant numbers of new committed progenitor cells (Loeffler and Roeder, 2002; Joseph and Morrison, 2005). Therapeutic stimulation of endogenous stem cells, therefore, has great potential for promoting oligodendrocyte production and remyelination in individuals with MS.

Cells with characteristics of stem cells can be isolated from the SVZ of the mammalian brain (Doetsch et al., 1999; Kukekov et

Received Feb. 26, 2009; revised March 25, 2009; accepted May 5, 2009.

This work was supported by National Institutes of Health-National Institute of Neurological Disorders and Stroke Grant R01 NS 29818 and by a postdoctoral fellowship from the National Multiple Sclerosis Society (C.W.).

Correspondence should be addressed to Bruce D. Trapp, Neurosciences Department, NC30, Lerner Research Institute, Cleveland Clinic, 9500 Euclid Avenue, Cleveland, OH 44195. E-mail: trappb@ccf.org.

D0I:10.1523/JNEUROSCI.1027-09.2009

Copyright $\odot 2009$ Society for Neuroscience $\quad$ 0270-6474/09/297649-09\$15.00/0 al., 1999; Roy et al., 2000; Menn et al., 2006). One population of such cells in the SVZ expresses glial fibrillary acidic protein (GFAP) and can generate multipotent neurospheres in vitro (Doetsch et al., 1997; Ganat et al., 2006). GFAP-positive cells are not the only source of neural precursors in the SVZ. The diverse spatial and temporal origin of oligodendrocyte lineage cells suggests that the mammalian CNS harbors several populations of stem cells with regionally and functionally specific potentials (Spassky et al., 1998; Kessaris et al., 2006; Menn et al., 2006; Yue et al., 2006).

A common model for studying primitive neural precursors in vitro is the neurosphere assay (Reynolds and Weiss, 1992; Reynolds and Rietze, 2005). When plated on adhesive surfaces, neurospheres generate neurons, astrocytes, and oligodendrocytes. Although neurosphere production was originally thought to be a characteristic of stem cells, transient amplifying cells and progenitor cells can also generate neurospheres (Doetsch et al., 2002; Belachew et al., 2003; Goldman and Sim, 2005). An assay system that selects primitive neural precursors from progenitor cells would represent a significant advance in stem cell research.

Here we have identified a population of cells within the SVZ of human brain that expresses $\beta 4$ tubulin ( $\beta \mathrm{T} 4$ ). The density of $\beta \mathrm{T} 4$ cells peaks during the latter stage of gliogenesis in the developing human brain and then decreases to adult densities shortly after birth. $\beta$ T 4 cells are increased adjacent to demyelinated lesions in MS brains. $\beta$ T4 cells are also present in neurospheres derived from the perinatal rat brain and can be enriched to $>95 \%$ homogeneity under growth-limiting conditions. Neurospheres derived from $\beta$ T4 cell-enriched cultures produce oligodendrocytes, neu- 
Table 1. Characteristics of MS tissues examined

\begin{tabular}{|c|c|c|c|c|c|c|c|}
\hline Pt\# & MS type & Disease duration & EDSS & Sex/age & Race & PMI (h) & \# Blocks ${ }^{a}$ \\
\hline 1 & SPMS & 15 years & 9.5 & $M / 53$ & C & 17.0 & 2 \\
\hline 2 & RRMS & 8 months & 6.0 & $M / 43$ & $C$ & 2.8 & 1 \\
\hline 3 & SPMS & 23 years & 8.0 & $\mathrm{M} / 46$ & C & 3.0 & 5 \\
\hline 4 & PPMS & 15 years & 6.5 & $\mathrm{~F} / 57$ & C & 5.5 & 2 \\
\hline 5 & SPMS & 33 years & 9.5 & $\mathrm{M} / 56$ & C & 3.0 & 5 \\
\hline 6 & SPMS & 9 years & 8.0 & $\mathrm{~F} / 63$ & C & 4.6 & 3 \\
\hline 7 & SPMS & 35 years & 9.5 & $F / 61$ & $\mathrm{~B} / \mathrm{AA}$ & 4.8 & 1 \\
\hline 8 & SPMS & 25 years & 7.5 & M52 & $C$ & 4.8 & 1 \\
\hline
\end{tabular}

${ }^{a}$ Every tissue block contained a periventricular demyelinated lesion. Seven blocks from four brains (1-4) also contained adjacent nonlesion areas.

SPMS, Secondary progressive multiple sclerosis; RRMS, relapsing remitting MS; PPMS, primary progressive MS; EDSS, expanded disability status scale; M, male; F, female; C, Caucasian; B/AA, black/African American; PMI, postmortem interval.

Table 2. Characteristics of adult control tissues examined

\begin{tabular}{|c|c|c|c|c|c|}
\hline Pt\# & Cause of death & Sex/age & Race & PMI (h) & \# Blocks \\
\hline 1 & Disseminated intravascular coagulation & $F / 47$ & $\mathrm{~B} / \mathrm{AA}$ & 15 & 2 \\
\hline 2 & Acute myocardial infarction & $\mathrm{F} / 65$ & $\mathrm{~B} / \mathrm{AA}$ & 7 & 2 \\
\hline 3 & Cardiopulmonary arrest & $\mathrm{F} / 53$ & B/AA & 36 & 3 \\
\hline 4 & Acute pericardial hemorrhage & $M / 65$ & $\mathrm{C}$ & 11 & 7 \\
\hline
\end{tabular}

Every tissue block contained periventricular tissue. C, Caucasian; B/AA, black/African American; F, female; M, male; PMI, postmortem interval.

rons, and astrocytes in vitro and myelinating oligodendrocytes when transplanted into the myelin-deficient (md) rat brain. Collectively, these results provide the first characterization of a primitive neural precursor cell that is capable of cell replacement in the mammalian brain.

\section{Materials and Methods}

Human tissue. Human tissue studies were approved by the Cleveland Clinic Institutional Review Board. MS brains were obtained from prospectively consented donors and characterized as described previously (Trapp et al., 1997, 1998; Chang et al., 2002). The adult control tissues were obtained from autopsies of patients without neurological disease performed at the Cleveland Clinic. Additional clinical details are listed in Tables 1 and 2. Developmental studies were performed on autopsy tissues from the Cleveland Clinic (17 postnatal months, death caused by acute myocardial infarction secondary to congenital heart disease) and Akron Children's Hospital (19 weeks after conception, other demographics unknown).

Cell culture. Rodent studies were approved by the Cleveland Clinic Institutional Animal Care and Use Committee. In primary neurosphere culture, $\sim 15$ postnatal day 4 (P4) rat pups were used for each experiment. Each pup was anesthetized by hypothermia and decapitated. The head was sterilized with 70\% isopropanol and transferred to a laminar flow hood equipped with a dissecting microscope. The skull was opened, and a $2 \mathrm{~mm}$ coronal slice was excised from the anterior cerebrum and discarded. The next $1-1.5 \mathrm{~mm}$ coronal slice was excised and transferred to a Sylgard-coated (Dow Corning) Petri dish containing minimal essential medium (MEM) (Invitrogen) on ice. Under the dissecting microscope, sections were attached to the dish with minutien pins (Fine Science Tools), and the lateral and medial SVZs were dissected using fine forceps and a dissecting knife. Dissected tissue was transferred to a Petri dish containing MEM. This process was repeated for each pup used. The combined dissected SVZs were minced with a scalpel blade, transferred to a $15 \mathrm{ml}$ Falcon tube (final MEM volume of $1.1 \mathrm{ml}$ ), and $400 \mu \mathrm{l}$ of trypsin (final concentration of $0.05 \%$; Cellgro/Mediatech) and $500 \mu \mathrm{l}$ of DNase (final concentration of $0.8 \mathrm{U} / \mu \mathrm{l}$; Sigma-Aldrich) were added. The mixture was incubated for $12-15 \mathrm{~min}$ at $37^{\circ} \mathrm{C}$ in a $\mathrm{CO}_{2}$ incubator, agitating the tube every $5 \mathrm{~min}$. The trypsin reaction was then quenched with $300 \mu \mathrm{l}$ of fetal bovine serum (FBS) (Hyclone). Plugged Pasteur pipettes (fire polished to approximately one-third diameter of the original size) were pre-wet with MEM, and cells were then separated by quick and gentle trituration (7-10 times) to yield a suspension of small aggregates. Tubes were fully filled with MEM and centrifuged at $166 \times g$ for 4 min at room temperature. The supernatant was then aspirated, and pellets were resuspended by triturating $\sim 10$ times in $\sim 1000 \mu \mathrm{l}$ of neurosphere me- dium (defined below) with the same polished Pasteur pipette used previously. The suspension was divided into three uncoated $75 \mathrm{~cm}^{2}$ flasks (approximately five pup brain SVZs per flask) in a final volume of 15 $\mathrm{ml} /$ flask and incubated for $4 \mathrm{~d}$ at $37^{\circ} \mathrm{C}, 5 \% \mathrm{CO}_{2}$ with no medium changes. Neurosphere medium was composed of DMEM/F-12 (Cellgro/Mediatech) supplemented with the following: $2 \mathrm{~mm}$ L-glutamine (GlutaMAX; Invitrogen), $100 \mathrm{IU} / \mathrm{ml}$ penicillin, $100 \mu \mathrm{g} / \mathrm{ml}$ streptomycin (Mediatech), $1 \% \mathrm{~N} 2$ supplement (Invitrogen), $20 \mathrm{ng} / \mathrm{ml}$ epidermal growth factor (EGF) (Sigma-Aldrich), and $20 \mathrm{ng} / \mathrm{ml} \mathrm{FGF2} \mathrm{(R} \mathrm{\&} \mathrm{D} \mathrm{Systems).}$

Secondary neurosphere culture. Coverslips (12 mm circular; Fisher Scientific) were coated with $0.1 \%$ poly-L-lysine (P1274; Sigma-Aldrich) for 40-60 min at room temperature, rinsed with distilled water three times, transferred to 24-well dishes, and air dried for at least $5 \mathrm{~min}$. Each flask of primary neurospheres was pelleted by centrifugation in a $15 \mathrm{ml}$ Falcon tube $(4 \mathrm{~min}$ at $166 \times \mathrm{g}$ ). Supernatant was discarded, and pellets were transferred with a plugged Pasteur pipette into a single Falcon tube for digestion (total final volume of $1.6 \mathrm{ml}$ ). Trypsin ( $400 \mu \mathrm{l}$, same stock as above) was added and incubated for $15 \mathrm{~min}$ at $37^{\circ} \mathrm{C}$. Digestion was quenched by adding $300 \mu \mathrm{l}$ of FBS. Digested primary neurospheres were then disaggregated using a fire-polished pipette with a diameter slightly larger (approximately two-thirds size of original pipette) than that used for triturating SVZ tissue. Pellets were triturated $\sim 15$ times, resulting in small aggregates. The tube was then filled with medium and spun for 4 min at $166 \times g$. Supernatant was removed, and the pellet was triturated $5-10$ times in $\sim 0.5 \mathrm{ml}$ of neurosphere medium. Cells were counted, and the suspension was diluted to a concentration of $\sim 150,000-200,000$ cells per $70-80 \mu \mathrm{l}$. This volume was plated into the center of the coverslips. After incubation for $20 \mathrm{~min}$ at room temperature, $500 \mu \mathrm{l}$ of preheated neurosphere medium containing $10 \mu \mathrm{M}$ cytosine $\beta$-D-arabinofuranoside hydrochloride (Ara C) (Sigma) was added and incubated at $37^{\circ} \mathrm{C}, 5 \%$ $\mathrm{CO}_{2}$ for $2 \mathrm{~d}$. The medium was then replaced with fresh preheated Ara $\mathrm{C}$-containing medium for an additional $2 \mathrm{~d}$. After 4 total days of Ara $\mathrm{C}$ treatment, coverslips were gently rinsed twice with $800 \mu \mathrm{l}$ of freshly prepared and preheated neurosphere medium. After this, $800 \mu \mathrm{l}$ of cold neurosphere medium was added, and dishes were placed on ice for 15-20 min. Medium was then carefully jetted at the edge of the coverslip using a $1000 \mu$ l pipette, until the confluent layer of cells on the coverslip detached from the glass surface. (A population of cells remained adherent to the coverslip after this treatment. Immunocytochemistry showed that the majority were GFAP-positive astrocytes.) The suspended cells were transferred to a $15 \mathrm{ml}$ Falcon tube and centrifuged for $4 \mathrm{~min}$ at $166 \times g$. The supernatant was aspirated, $1 \mathrm{ml}$ of neurosphere medium was added, and the pellet was gently resuspended by trituration (three to four times). This suspension was transferred to an uncoated $75 \mathrm{~cm}^{2}$ flask in a total volume of $15 \mathrm{ml}$ and incubated for $3 \mathrm{~d}$. Differentiation of secondary 
neurospheres was achieved by plating secondary neurospheres onto poly-L-lysine-coated coverslips in neurosphere medium for $7 \mathrm{~d}$.

A2B5 immunopanning. A2B5-positive cells were isolated by immunopanning of $\mathrm{P} 4$ dissociated forebrain cells as described by Barres et al. (1992). Briefly, $100 \mathrm{~mm}$ dishes were coated with $5 \mu \mathrm{g} / \mathrm{ml}$ goat anti-mouse IgM antibody (Cappel) in $20 \mathrm{ml}$ of $0.05 \mathrm{M} \mathrm{Tris} / \mathrm{HCl}, \mathrm{pH} 9.5$, at $4^{\circ} \mathrm{C}$ overnight. The plates were washed three times with PBS. An A2B5 hybridoma supernatant was prepared from Clone 105 from the American Type Culture Collection by the Lerner Research Institute Hybridoma Core. Six milliliters of a 1:3 dilution of supernatant stock were added to each plate, incubated at room temperature for $2 \mathrm{~h}$, and rinsed three times with PBS. Dissociated cells from two P4 rat forebrains were diluted in 24 $\mathrm{ml}$ of DMEM/F-12, divided into four coated plates, and incubated at $37^{\circ} \mathrm{C}, 5 \% \mathrm{CO}_{2}$ for $30 \mathrm{~min}$. The fluid was removed, plates were washed three times with DMEM/F-12, and adherent cells were dislodged by trituration. These cells were centrifuged, resuspended in DMEM/F-12, and quantified. Cell concentration was adjusted to $\sim 25,000$ cells per $5 \mu \mathrm{l}$ for transplantation. Aliquots of immunopanned cells were also immediately plated onto coverslips for double labeling with A2B5 and polysialic acidneural cell adhesion molecule (PSA-NCAM) antibodies.

Transplantation. md rats (gift from Dr. Wendy B. Macklin, University of Colorado Denver School of Medicine, Aurora, CO) were transplant recipients of $\beta \mathrm{T} 4$ secondary neurospheres or A2B5-positive cells. P3 rats were anesthetized by hypothermia, and $\sim 25,000 \beta \mathrm{T} 4$ cells ( 120 secondary neurospheres) or immunopanned A2B5-positive cells in a volume of $5 \mu \mathrm{l}$ of DMEM/F-12 were stereotactically injected into the left striatum ( $0.4 \mathrm{~mm}$ anterior to bregma, $2.3 \mathrm{~mm}$ lateral to midline, and $3.0 \mathrm{~mm}$ deep). After $17 \mathrm{~d}$, rats were transcardially perfused with $4 \%$ paraformaldehyde. Serial $30 \mu \mathrm{m}$ coronal sections of the transplanted cerebral hemispheres were cut, and every fourth section was immunofluorescently stained for proteolipid protein (PLP). Sections spaced at $240 \mu \mathrm{m}$ intervals were imaged using confocal microscopy, and myelin areas/volumes were measured directly in NIH ImageJ software. Three-dimensional reconstructions were generated using Reconstruct software (Fiala, 2005) and assembled in Photoshop software (Adobe Systems) to provide graphical representations of myelin distributions.

Immunostaining. Tissue immunohistochemistry was performed on paraformaldehyde-fixed free-floating sections (Trapp et al., 1997, 1998; Chang et al., 2002). Sections used for double-labeling experiments were incubated with two primary antibodies for 3-5 d, followed by fluorescently labeled and biotinylated secondary antibodies for $1-2 \mathrm{~h}$. Antibodies and dilutions used on tissue sections were as follows: class IV $\beta$ tubulin (1:10,000; Sigma), Tuj1 (1:1000; Covance), GFAP (1:10,000; Dako), Iba1 (1:4000; gift from Dr. Shinichi Kohsaka, National Institute of Neuroscience, Tokyo, Japan), NG2 (1:250; Millipore Bioscience Research Reagents), PLP (1:400; Agmed), PSA-NCAM (1:200; BD Pharmingen), goat anti-rat IgG biotinylated (1:1000; Vector Laboratories), goat antimouse IgG biotinylated (1:1000; Vector Laboratories), goat anti-mouse IgG Alexa (1:1000; Invitrogen), goat anti-rabbit FITC (1:1000; Invitrogen), goat anti-mouse IgG1 FITC (1:1000; Invitrogen), goat anti-mouse IgG2a Alexa (1:1000; Invitrogen), goat anti-rabbit IgG Alexa (1:1000; Invitrogen), goat anti-rabbit IgG biotinylated (1:1000; Vector Laboratories), and goat anti-mouse IgM biotinylated (1:1000;Vector Laboratories).

Neurospheres from suspension cultures were attached to coverslips for $15 \mathrm{~min}$ before fixation with $4 \%$ paraformaldehyde for $30 \mathrm{~min}$, treatment with $10 \%$ goat normal serum/0.1\% Triton X-100/PBS (1 h), and sequential incubation with primary and appropriate fluorescently labeled secondary antibodies. Staining of bromodeoxyuridine (BrdU)treated cultures included pretreatment with $2 \mathrm{~N} \mathrm{HCl}(1 \mathrm{~h})$ and $0.1 \mathrm{M}$ sodium borate, $\mathrm{pH} 8.6$ (30 $\mathrm{min})$, followed by application of FITCconjugated monoclonal anti-BrdU antibody (1:20; Abcam) overnight at $4^{\circ} \mathrm{C}$. The following other primary and secondary antibodies and dilutions we used included the following: class IV $\beta$ tubulin (1:15,000; Sigma), Tuj1 (1:200; Covance), GFAP (1:10,000; Dako), O4 (1:5; gift from Dr. Robert Miller, Case Western Reserve University School of Medicine, Cleveland, OH), A2B5 (1:40; gift from Dr. Robert Miller), NG2 (1:100; Millipore Bioscience Research Reagents), PLP (1:1000; Agmed), PSANCAM (1:100; BD Pharmingen), goat anti-rat IgG biotinylated (1:1000;
Vector Laboratories), goat anti-mouse IgG Alexa (1:1000; Invitrogen), goat anti-rabbit FITC (1:1000; Invitrogen), goat anti-mouse IgM FITC (1:500; Southern Biotechnology Associates), and goat anti-rabbit IgG Alexa (1:1000; Invitrogen). 4',6-diamidino-2-phenylindole (DAPI) was included in the mounting medium (Vectashield; Vector Laboratories) for nuclear detection.

Microscopy. Bright-field and epifluorescence images were obtained using a Leica DMR microscope (W. Nuhsbaum Inc.) equipped with an Optronix Magnafire digital camera and processed using Photoshop software (Adobe Systems). Double immunofluorescence was evaluated by confocal microscopy. Confocal microscopy was performed on a Leica TCS-NT microscope using $63 \times$ [1.4 numerical aperture (NA) $]$ and $40 \times$ (1.0 NA) lenses or on a Leica SP5 confocal microscope using $63 \times(1.4$ NA), $40 \times(1.25 \mathrm{NA})$, and $10 \times(0.4 \mathrm{NA})$ lenses. Myelin volumes were measured from serial $30 \mu \mathrm{m}$ coronal sections of rat brain, spaced as 240 $\mu \mathrm{m}$ intervals, and immunofluorescently stained for PLP. Areas with myelin were imaged as single confocal sections at $10 \times$ (pixel density, $2048 \times$ 2048 ) on the SP5 confocal microscope. In NIH Image J software, regions of interest that included the myelin were created and then automatically thresholded to count only fluorescent pixels. Myelin areas per section were interpolated across serial sections to provide an estimate of myelin volume in each brain. For three-dimensional reconstructions, selected slices were imaged at $2.5 \times$ in an epifluorescence microscope, and myelin was traced and reconstructed using Reconstruct software (Fiala, 2005).

Statistical analyses. Nonpaired Student's $t$ tests were used for all statistical comparisons $(\alpha=0.05)$. In Figure $1 E, \beta T 4$ cells in human SVZ were counted, and data were expressed with respect to length of SVZ examined (cells per millimeter). Twenty periventricular demyelinated lesions from eight MS brains and 14 periventricular areas from four control brains were evaluated. Seven lesions from four of the brains had adjacent nonlesion areas for analysis. For comparison of MS and control $\beta$ T4 cells, all counts from each brain were combined ( $n=8$ for MS and 4 for control). The percentage of $\beta$ T4-positive cells was determined in control and Ara $\mathrm{C}$-treated cultures by counting $\beta$ T4-positive and DAPI-positive cells in 10 randomly selected fields using standard fluorescence microscopy. Data from three independent experiments were used for statistics. In supplemental Figure S1C (available at www.jneurosci.org as supplemental material), the percentage of $\beta$ T4-positive cells was determined in control and Ara C-treated cultures by counting $\beta$ T4-positive and DAPIpositive cells in 10 randomly selected fields using standard fluorescence microscopy. Data from three independent experiments were used for statistics.

\section{Results}

\section{$\boldsymbol{\beta}$ T4-positive cells in the human SVZ}

We previously detected $\beta \mathrm{T} 4$ in rat oligodendrocytes and discussed in detail the tissue distribution and difficulties in ascribing cell-specific functions of $\beta$ tubulin isotypes (Terada et al., 2005). Application of $\beta$ T4 antibodies to adult human brain sections demonstrated three distinct cell populations: oligodendrocytes (which stained weakly), ependymal cells, and a previously unidentified cell population in the SVZ (Fig. $1 A$, arrows). We compared the distribution of $\beta \mathrm{T} 4$ in tissue sections from normal adult brain and from brains of individuals with MS. In adult control brains, $\beta \mathrm{T} 4$ antibodies intensely stained a population of cells that lined the SVZ of the lateral ventricles (Fig. $1 A$, arrows). We call this population of cells " $\beta$ T4 cells." $\beta$ T4 cells often appeared as doublets (Fig. $1 A$ ), had sparse perinuclear cytoplasm, and, when viewed at higher magnification, had thin processes (Fig. 1B). Compared with control brains, $\beta \mathrm{T} 4$ cells were more abundant in SVZs that bordered demyelinated areas in MS brains (Fig. 1C), and doublets and clusters of cells were more frequent (Fig. 1D). The average number of $\beta \mathrm{T} 4$ cells in the SVZ of adult control brain was $4 / \mathrm{mm}$ SVZ length and was not different from that in SVZs bordering nonlesion white matter in sections from MS brains ( 3 cells/mm SVZ length; $p=0.47$ ) (Fig. $1 E$ ). $\beta$ T4 cell density in SVZs that bordered demyelinated regions of the MS 
brains was 23 cells/mm SVZ length and was significantly increased compared with both adjacent nonlesion areas $(p<0.001)$ and control brain SVZs $(p<0.001)$. These data support the concept that $\beta$ T4 cells represent a dynamic cell population in the adult human SVZ that can expand locally in response to demyelination and oligodendrocyte destruction.

$\beta$ T4-positive cells in the human SVZ do not express astrocytic, microglial, oligodendrocytic, or neuronal markers To phenotype $\beta$ T4-positive cells, sections of human brain SVZ were stained for $\beta \mathrm{T} 4$ and markers specific for or enriched in characterized CNS cells. $\beta$ T4 cells did not express detectable levels of GFAP (Fig. $1 \mathrm{~F}$ ), a protein expressed by a subpopulation of neuroectodermal stem cells and mature astrocytes (Doetsch et al., 1997). $\beta$ T4 cells did not colabel with markers for microglia (Iba1) (Fig. 2A) or mature oligodendrocytes (PLP) (Fig. 2B), and the distribution and morphology of $\beta \mathrm{T} 4$ positive cells (Fig. 2C) was different from OPCs expressing NG2 (Fig. 2D) and neuronal progenitor cells expressing PSANCAM (Fig. 2E) (Alvarez-Buylla and Garcia-Verdugo, 2002; Bonfanti, 2006). A subset of ependymal cells expressed $\beta \mathrm{T} 4$ (Fig. 1A, $C$, asterisks), consistent with previous observations of this tubulin isotype in ciliated cells (Woo et al., 2002).

\section{$\beta T 4$ cells have a dynamic spatial and temporal distribution in the developing telencephalon}

The combination of location and immunophenotype described above suggests that $\beta \mathrm{T} 4$ cells represent a pre-progenitor cell related to oligodendrogenesis and, as such, may have a dynamic distribution in the developing human brain. Generation of telencephalic glial progenitor cells occurs in several waves during mammalian brain development (Kessaris et al., 2006). It begins ventrally in the medial ganglionic eminence and progresses dorsally so that, in the latter stages, the SVZ of the entire lateral ventricular area contributes to gliogenesis. The density and distribution of SVZ $\beta$ T4 cells in sections from fetal human brain were correlated with latter stages of gliogenesis. At 19 weeks after conception (Fig. $3 A-D$ ), for example, the density of SVZ $\beta$ T4positive cells is high in the most ventral (inferior) regions of the lateral ventricles (Fig. 3B), intermediate in the septal (Fig. 3C, top) and callosal (Fig. $3 D$, top) walls, and very low in the expanded SVZ (Fig. $3 A, C, D$, asterisks), which overlies the caudate nucleus and is enriched in Tuj1-positive neuronal progenitors. Double labeling of this region demonstrates that $\beta$ T 4 cells are distinct from Tuj1-positive cells (Fig. 3E). SVZ $\beta$ T4 cells do not express detectable levels of GFAP, consistent with adult human brain (Fig. $3 F$ ). By 17 postnatal months, SVZ $\beta$ T4 cells are present in all regions of the lateral ventricles (Fig. $3 G$ ), in which their density is slightly higher ( $\sim 9$ cells/mm SVZ) than in normal adult brain. In summary, $\beta$ T 4 cell density and distribution peak during the latter stage of gliogenesis in the developing human brain and then decrease to adult densities shortly after birth.

$\boldsymbol{\beta}$ T4-positive cells are a slowly proliferating primitive neural precursor population in the rodent periventricular forebrain

To further elucidate the properties of $\beta \mathrm{T} 4$ cells, we investigated their morphology and activity in neurospheres generated from neonatal rat brain SVZ (Fig. 4A). Periventricular tissue from P4 rat brain was dissociated, placed into a standard neurosphere culture medium for $4 \mathrm{~d}$, plated onto coverslips, and assayed for the presence of $\beta \mathrm{T} 4$ cells. $\beta \mathrm{T} 4$-positive cells were present in a small portion of primary neurospheres; when present, they represented the vast majority of the cells in the individual neurospheres (Fig. $4 A, B$ ). In general, $\beta$ T 4 cell-enriched neurospheres were smaller than non- $\beta$ T4 cell neurospheres; $\beta$ T4 cells represented $<2 \%(1.33 \pm 2.06 \%)$ of the total primary neurosphere cells. We next investigated whether the $\beta \mathrm{T} 4$ cells were actively dividing as they formed primary neurospheres. After a $20 \mathrm{~h} \mathrm{BrdU}$ pulse, nuclei in many cells in $\beta$ T4-negative neurospheres were labeled (Fig. $4 C$ ). In contrast, $\sim 95 \%$ of the $\beta$ T4-positive neurospheres contained no BrdU-labeled cells; the remaining 5\% had one or two BrdU-positive $\beta \mathrm{T} 4$ cells (Fig. $4 C$ ), suggesting that $\beta$ T4-containing neurospheres formed by homophilic cell adhesion and not by proliferation.

The low level of $\beta$ T4 cell proliferation and high rate of $\beta$ T4negative cell proliferation provided a mechanism for $\beta \mathrm{T} 4$ cell enrichment. Primary neurospheres were dissociated and grown 

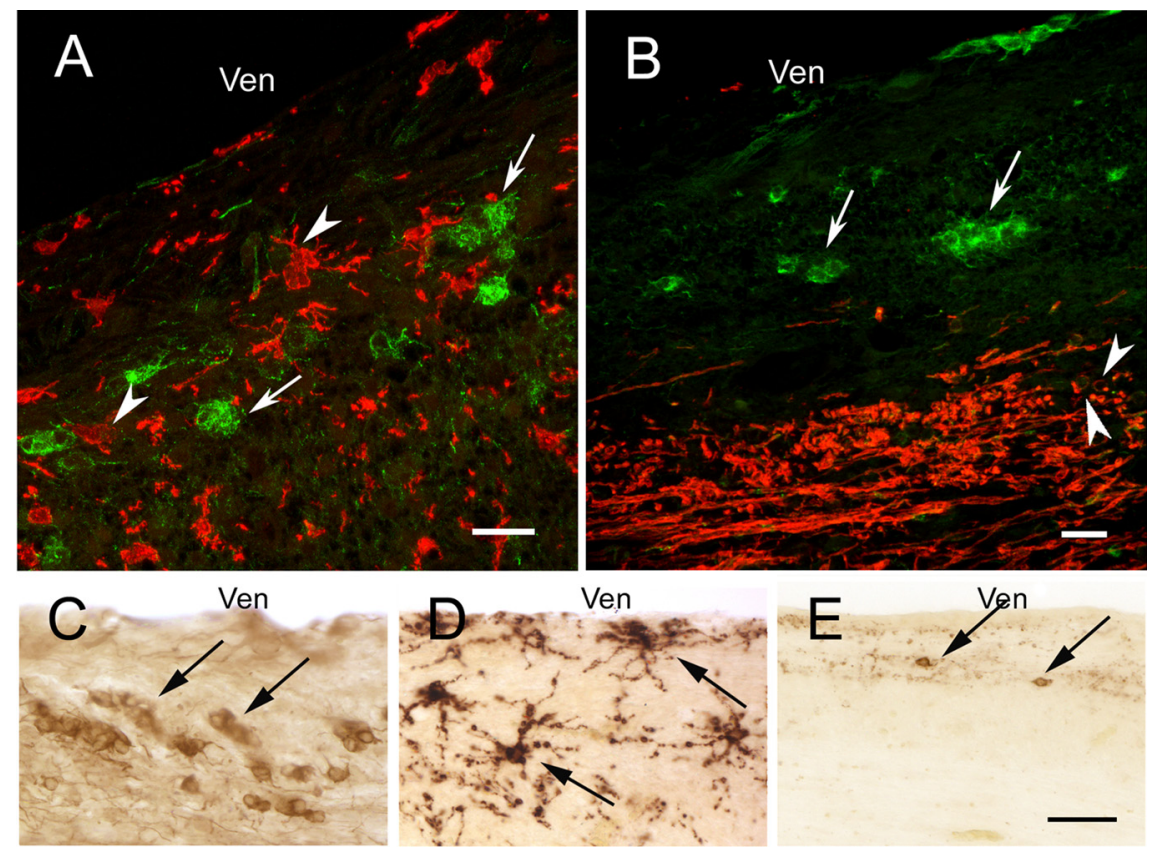

Figure 2. $\quad \beta T 4$ cells in the subventricular zone of the adult human brain do not express markers specific for characterized CNS cells. $\beta$ T4 cells ( $\boldsymbol{A}, \boldsymbol{B}, \beta 4$ tubulin, green, arrows) do not express markers specific for microglia ( $\boldsymbol{A}$, Iba1, red, arrowheads) or oligodendrocytes ( $\boldsymbol{B}$, PLP, red, arrowheads). In serially cut sections stained for individual antigens, the morphology and distribution of $\beta T 4$ cells ( $\boldsymbol{C}$, arrows) are distinct from NG2-positive oligodendrocyte progenitor cells ( $\boldsymbol{D}$, arrows) or PSA-NCAM-positive committed neuronal progenitor cells ( $\boldsymbol{E}$, arrows). Ven, Lateral ventricle. Scale bars: $\boldsymbol{A}, \boldsymbol{B}, 20 \mu \mathrm{m} ; \boldsymbol{C}-\boldsymbol{E}$, $50 \mu \mathrm{m}$.
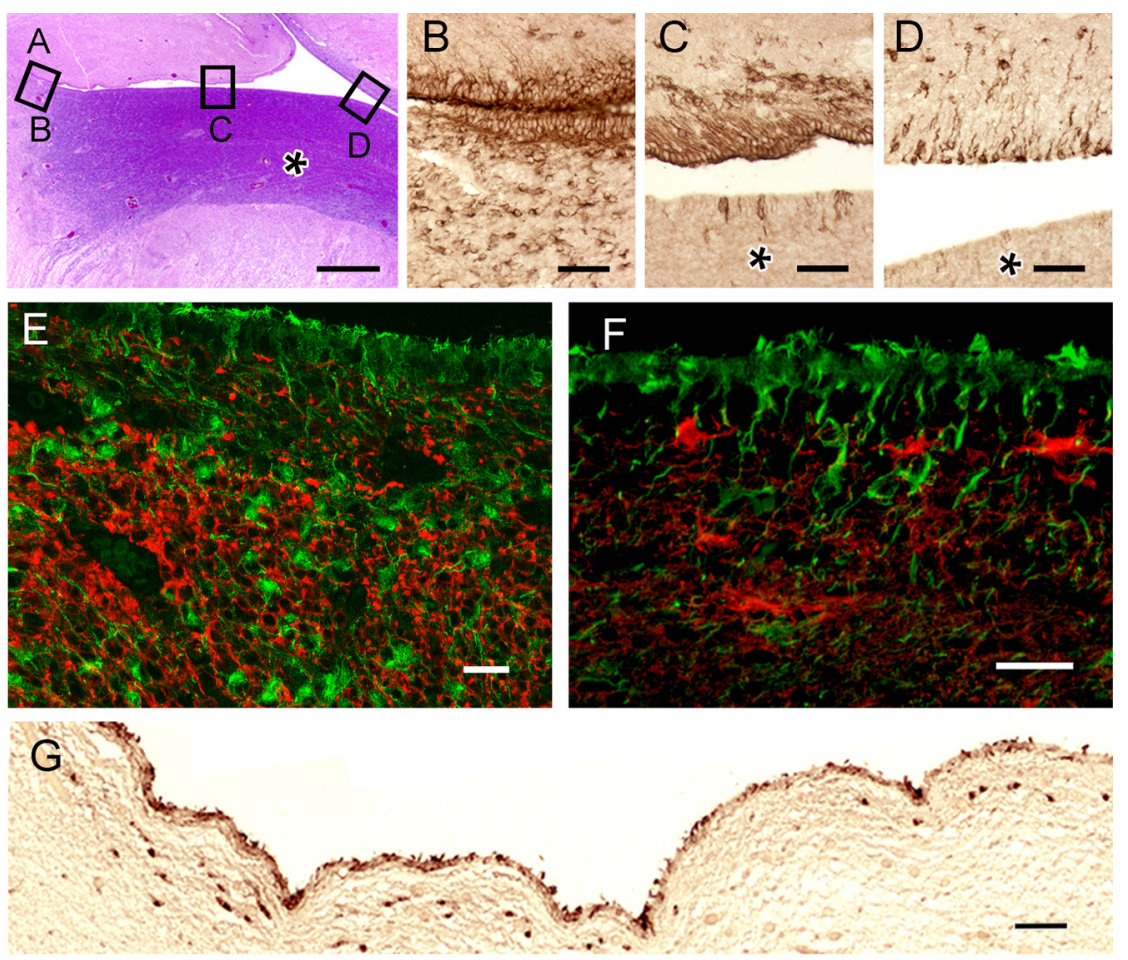

Figure 3. $\quad \beta T 4$ cells have a dynamic spatial and temporal distribution in the developing human telencephalon. $\boldsymbol{A}$, Hematoxylin and eosin-stained section of cerebrum surrounding lateral ventricle at 19 weeks after conception. Left is inferior (ventral), and top is medial. Asterisk $(\boldsymbol{B}, \boldsymbol{C}, \boldsymbol{D})$ indicates the expansion of the SVZ overlying the caudate nucleus that is present at this age. Boxes identify the regions shown in $\boldsymbol{B}-\boldsymbol{D}$. $\beta$ T4 cells are most abundant inferiorly $(\boldsymbol{B})$ and more frequent in the septal $(\boldsymbol{C}$, top) and callosal $(\boldsymbol{D}$, top) walls compared with the lateral wall $(\boldsymbol{C}, \boldsymbol{D}$, bottom). $\boldsymbol{E}, \boldsymbol{F}, \beta \mathrm{T} 4$ cells do not show evidence of neuronal or astroglial phenotypes ( $\boldsymbol{E}, \beta T 4$, green, Tuj1, red; $\boldsymbol{F}, \beta T 4$, green, GFAP, red). $\boldsymbol{G}$, At 17 postnatal months, SVZ $\beta T 4$ cells have a morphology and distribution similar to adult brain. Scale bars: $\boldsymbol{A}, 1 \mathrm{~mm} ; \boldsymbol{B}-\boldsymbol{D}, 50 \mu \mathrm{m} ; \boldsymbol{E}, \boldsymbol{F}, 20 \mu \mathrm{m} ; \boldsymbol{G}, 100 \mu \mathrm{m}$. in the presence or absence of the mitotic inhibitor Ara C for $4 \mathrm{~d}$ (Fig. 4A). Treatment with Ara $\mathrm{C}$ resulted in a dramatic enrichment of $\beta \mathrm{T} 4$ cells. The marked proliferation of $\beta \mathrm{T} 4$-negative cells diluted $\beta$ T 4 cells to $<0.03 \%$ of the total cells in the absence of Ara C (supplemental Fig. S1, available at www.jneurosci.org as supplemental material). In contrast, after $4 \mathrm{~d}$ of treatment with Ara C, $83.2 \%$ of the dissociated cells were $\beta$ T4 positive (supplemental Fig. S1, available at www.jneurosci.org as supplemental material). This represents a 2700 -fold enrichment in plated $\beta$ T4 cells $(p<0.001)$. This enrichment was enhanced when Ara C-treated cells were detached from the coverslips and placed into suspension culture for $4 \mathrm{~d}$ in the presence of EGF and FGF2, producing neurospheres. These secondary neurospheres were then attached to coverslips and stained for $\beta$ T4 and nuclei. More than $95 \%$ of the secondary neurospheres were $\beta \mathrm{T} 4$ cell positive (Fig. $4 D$ ). In these $\beta \mathrm{T} 4$ cell-positive secondary neurospheres, $\beta \mathrm{T} 4$ cells represented $98.9 \pm 1.9 \%$ of the cells, a significant increase in purity compared with $\beta \mathrm{T} 4$ cells in primary neurospheres, which represented only $1.33 \pm 2.06 \%(n=$ $40 ; p<0.001)$. $\beta$ T4 cell-enriched secondary neurospheres were relatively resistant to enzymatic and mechanical dissociation protocols, a property of purified cultures of embryonic stem cells (Thomson et al., 1998) and primordial germ cells (Shamblott et al., 1998). These observations support the hypothesis that the $\beta \mathrm{T} 4$ cellenriched neurospheres were composed of slowly dividing primitive neural precursors and not transient amplifying or committed progenitor cells.

\section{Secondary neurospheres generate neurons, astrocytes, and oligodendrocytes in vitro}

To define the molecular characteristics of $\beta \mathrm{T} 4$ cells, primary and $\beta \mathrm{T} 4$ cell-enriched secondary neurospheres were adhered to coverslips, immediately fixed, and labeled with cell-type-specific antibodies. Similar to human brain tissue sections, $\beta \mathrm{T} 4$ cells did not express markers specific for astrocytes, OPCs (supplemental Fig. S2, available at www.jneurosci.org as supplemental material), oligodendrocytes, or neurons (data not shown). However, plating on coverslips for $6 \mathrm{~h}$ allowed migration of $\beta$ T4 cells away from the neurosphere. After losing this contact inhibition, the $\beta \mathrm{T} 4$ cells incorporated BrdU and underwent cell division in $24 \mathrm{~h}$ (Fig. 5A). One of the characteristics of organ-specific neural stem cells or primitive cells is the capability 
to produce all cell types of that organ. Therefore, we examined parallel cultures after seven days. $\beta$ T4 cell-enriched secondary neurospheres generated Tuj1positive neurons (Fig. 5B), O4-positive oligodendrocytes (Fig. 5C), and GFAPpositive astrocytes (Fig. 5D). The proportion of these three cell types generated varied with media composition. Standard neurosphere media (N2, EGF/FGF) favored generation of astrocytes, whereas more oligodendrocytes and neurons were generated in the presence of sonic hedgehog (data not shown).

\section{Secondary neurospheres produce} myelinating oligodendrocytes in vivo To test the potential of $\beta \mathrm{T} 4$ cells to respond to in vivo cues and produce oligodendrocytes, $120 \beta$ T4 cell-enriched secondary neurospheres $(25,000 \quad \beta$ T4 cells) were injected into the right striatum of $\mathrm{P} 3$ $\mathrm{md}$ rat pups. The $\mathrm{md}$ rat has a mutation in the PLP gene (Boison and Stoffel, 1989), severe hypomyelination (Dentinger et al., 1982), and no detectable PLPsurrounding axons (Learish et al., 1999). The presence of PLP around axons after transplantation, therefore, reflects myelination by progeny of the $\beta \mathrm{T} 4$-positive secondary neurosphere cells. Because md rats die by P25, transplanted rats were killed at P20 and examined for PLP-positive myelin sheaths. During this $17 \mathrm{~d}$ time span, progeny of the injected $\beta$ T 4 cells migrated up to $4 \mathrm{~mm}$ and produced oligodendrocytes, which then myelinated axons throughout the external capsule on the injected side of the brain (supplemental Fig. S3, available at www.jneurosci.org as supplemental material). To establish the extent of $\beta \mathrm{T} 4$ cell-derived myelination, seven $\beta$ T 4 cell-transplanted md rat brains were serially sectioned and stained for PLP. The three-dimensional distribution of PLP-positive myelin internodes was reconstructed and quantified (Fig. 6A-D) (supplemental Fig. S3, available at www.jneurosci.org as supplemental material). PLP-positive myelin was present anterior, posterior, caudal, and rostral to the injection site at rostrocaudal distances of up to $4.0 \mathrm{~mm}$. At sites closest to the injection site, thousands of axons in the external capsule were myelinated (Fig. 6I). At sites distal to the injection site, premyelinating PLPpositive oligodendrocytes and oligodendrocytes in early stages of myelination were abundant (supplemental Fig. S4, available at www.jneurosci.org as supplemental material), indicating that the repair potential of transplanted $\beta$ T4 cell progeny had not been exhausted during the $17 \mathrm{~d}$ postinjection period. This extent of mature CNS cell generation and differentiation by a relatively small number of transplanted cells in a $17 \mathrm{~d}$ time span is unprecedented and provides in vivo support for the therapeutic potential of purified populations of $\beta$ T 4 cells.

We next compared the myelination potential of transplanted $\beta \mathrm{T} 4$ cell-positive secondary neurospheres with transplanted
A2B5-positive cells. The A2B5 monoclonal antibody recognizes a group of sialogangliosides expressed by immature neuroectodermal cells and is commonly used to isolate OPCs. A2B5-positive cells obtained from $\mathrm{P} 4$ wild-type rat forebrains are a mixture of PSA-NCAM-negative oligodendrocyte progenitors (77\%) and PSA-NCAM-positive cells (23\%) that include oligodendrocyte pre-progenitors (Grinspan and Franceschini, 1995; Ben-Hur et al., 1998) and possibly immature neurons (Windrem et al., 2004; Bonfanti, 2006). Seven md rat pups received intracerebral injections of 25,000 A2B5-positive cells. Brains were analyzed for PLPpositive myelin at $\mathrm{P} 20$ as described above. In the A2B5-positive cell transplanted brains, myelination was detected (Fig. $6 E-H, J$ ) (supplemental Fig. S3, available at www.jneurosci.org as supplemental material), but A2B5 cells produced only $37 \%$ of the myelin volume $\left(0.06 \pm 0.02 \mathrm{~mm}^{3}\right)$ compared with md brains transplanted with $\beta$ T4 cell-positive secondary neurospheres $(0.18 \pm$ $\left.0.03 \mathrm{~mm}^{3} ; p=0.014\right)$, and the rostrocaudal extent of myelination $(1.75 \pm 0.23 \mathrm{~mm})$ was $<60 \%$ that of $\beta \mathrm{T} 4$ cells $(2.98 \pm 0.24 \mathrm{~mm}$; $p=0.003)$. 

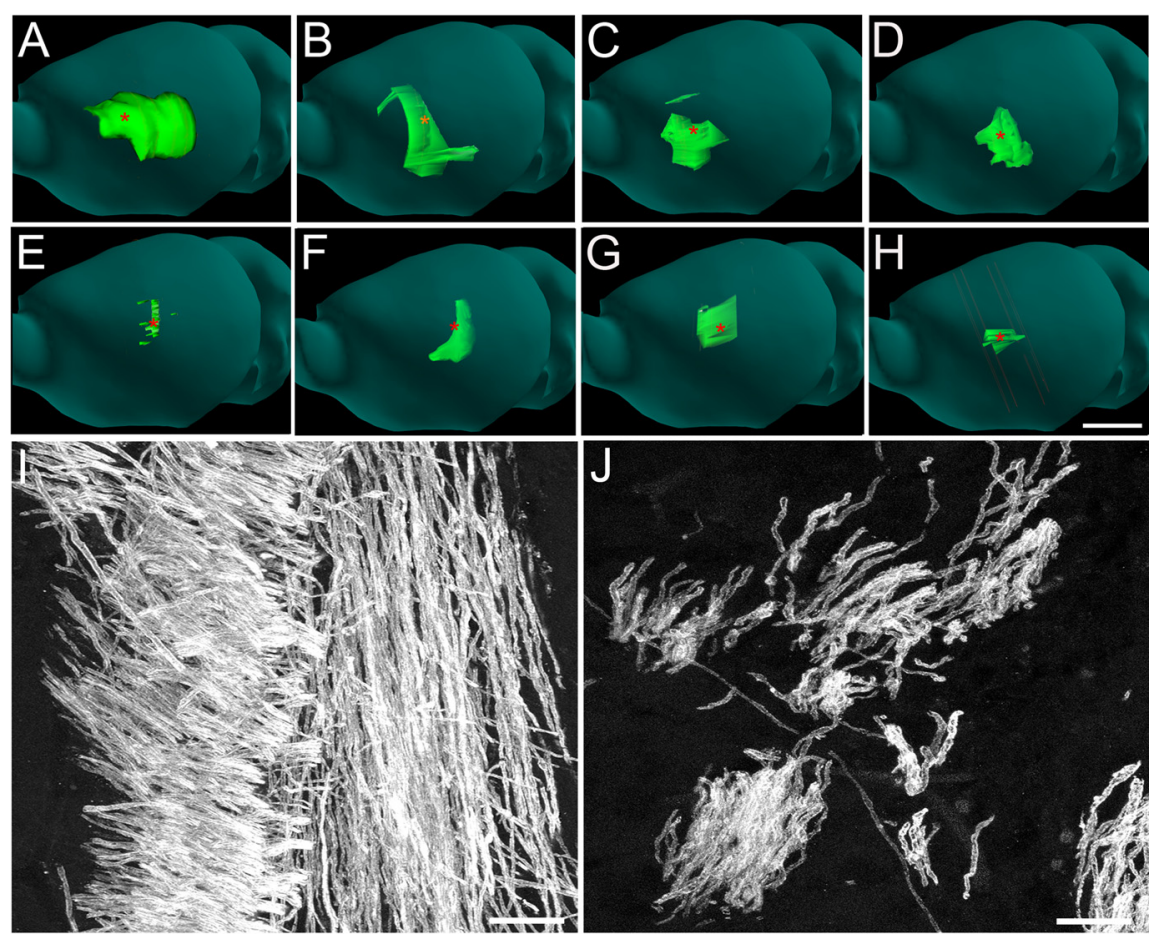

Figure 6. $\quad \beta$ T4-enriched secondary neurospheres showed greater potential for myelination than A2B5-positive cells when transplanted into md rat brains. $\boldsymbol{A}-\boldsymbol{D}$, Representative serially sectioned and reconstructed P20 md rat brains stained for PLP (green) after injection of $120 \beta$ T4 cell-positive secondary neurospheres ( $\sim 25,000 \beta$ T4 cells) on P3. PLP-positive myelin was present anterior, posterior, caudal, and rostral to the injection site (marked by red asterisks) at rostrocaudal distances up to $4 \mathrm{~mm}$ (4 of 7 brains shown). $\boldsymbol{E}-\boldsymbol{H}$, Representative serially sectioned and reconstructed P20 md rat brains stained for PLP (green) after injection of 25,000 A2B5-positive cells on P3 (4 of 7 brains shown). Compared with secondary neurosphere transplantation, A2B5-positive cell transplantation produced less PLP-positive myelin, which was mostly scattered about the injection site. I, Thousands of myelinated axons were present in the external capsule close to the injection site of $\beta$ T4-positive secondary neurospheres. $\boldsymbol{J}$, Fewer myelinated axons were observed after A2B5-positive cell transplantation. Scale bars: $\boldsymbol{A}-\boldsymbol{H}, 5 \mathrm{~mm} ; \boldsymbol{I}, \boldsymbol{J}, 10 \mu \mathrm{m}$.

Transplantation of wild-type cells into md rat brain permits identification of myelinating oligodendrocytes originating from the transplanted cells. Neurons and astrocytes derived from the transplanted cells cannot be distinguished from endogenous md rat cells. Transplantation of $\beta \mathrm{T} 4$ neurospheres derived from enhanced green fluorescent protein-expressing rat cells (Inoue et al., 2005) resulted in astrocyte, but not neuron, production (data not shown). This is not surprising because neurogenesis is mostly complete at the time of transplantation.

\section{Discussion}

We describe a novel cell population in the human and rodent CNS SVZ. It is a newly identified source for producing mature oligodendrocytes in the CNS. These cells, identified by labeling with $\beta$ T4 antibodies, express a number of characteristics commonly associated with primitive neuroepithelial cells. First, $\beta$ T4 cells have a low basal rate of proliferation and can be enriched 2700 -fold through antimitotic removal of transient amplifying and progenitor cells from rat brain primary neurospheres. Second, $\beta$ T4 cells form neurospheres by homophilic adhesion and become contact inhibited, but they retain the capacity to produce oligodendrocytes, neurons, and astrocytes when attached to a substrate. Third, when transplanted into md rat brains, their progeny display an unprecedented potential to myelinate and to replace defective CNS myelin. Although it remains to be determined whether $\beta$ T4 cells have the canonical stem cell property of continuous self-renewal, their in vitro properties, persistence in the SVZ of the adult CNS, and remarkable capacity to produce myelinating oligodendrocytes in a pathological environment identifies them as a novel and primitive neural precursor cell.

We exploited two fundamental stem cell characteristics, low basal rates of proliferation and homophilic adhesion during dissociation, to purify $\beta \mathrm{T} 4$ cells from rodent brain. By selectively killing dividing cells in primary neurospheres, we exploited the low basal rate of $\beta \mathrm{T} 4$ cell division to obtain enriched populations of $\beta \mathrm{T} 4$ cells in vitro. Our BrdU incorporation studies support that $\beta \mathrm{T} 4$ cell-enriched neurospheres are not formed by $\beta \mathrm{T} 4$ cell proliferation. After enrichment in secondary neurospheres, $\beta$ T 4 cells were resistant to dissociation by enzymes, $\mathrm{Ca}^{2+}$ chelators, and/or mechanical dissociation, characteristics shared with embryonic stem cells and primordial germ cells (Shamblott et al., 1998; Thomson et al., 1998), making it impossible to examine $\beta$ T4 cells in single-cell colony or clonal assays. These observations support our interpretation that $\beta \mathrm{T} 4$ cell-enriched secondary neurospheres form by homophilic adhesion. Homophilic adhesion contact inhibits $\beta$ T4 cell division and differentiation when secondary neurospheres are formed and maintained in suspension. However, when plated on adhesive surfaces, this contact inhibition is partially released as most BrdU-positive $\beta$ T4 cells (after a $20 \mathrm{~h}$ pulse) were migrating away from the secondary neurospheres.

The extent of oligodendrocyte generation and myelination that we describe in the md rat brain is unprecedented, considering that only $25,000 \beta \mathrm{T} 4$ cells were transplanted and brains were examined after only $17 \mathrm{~d}$. In addition, production of myelinating oligodendrocytes was still occurring at the time of perfusion (supplemental Fig. S4, available at www.jneurosci.org as supplemental material), indicating that the repair capabilities of cells generated from transplanted $\beta$ T4 cells were still active. Compared with A2B5-positive progenitor cells, transplanted $\beta$ T4-positive cells generated $270 \%$ more myelin over a significantly greater brain volume. Achieving a rapid and wide distribution of myelin is important for transplantation therapies. For example, transplantation of human fetal A2B5-positive cells into the shiverer mouse mutant results in extensive myelination (Windrem et al., 2004), but multiple transplantation sites are required to rescue the phenotype (Windrem et al., 2008). The precise mechanism by which a wider spatial distribution of myelin produced from $\beta$ T4 cell transplants is unknown. Our in vitro results predict that exposure of the neurosphere to extracellular matrix provides signals that stimulate migration away from the neurosphere and proliferation via an intermediate transient amplifying cell before differentiation into OPCs. This enables a cascade because OPCs also have the capacity for migration and proliferation.

Our studies identify $\beta \mathrm{T} 4$ cells as a distinct and previously undefined population of precursor cells in the SVZ of the mammalian CNS. They do not express markers specific for committed oligodendrocyte progenitor cells (NG2 or A2B5) or mature neu- 
rons or oligodendrocytes. Previous studies have characterized a stem cell of the fetal and adult SVZ that expresses GFAP (GarciaVerdugo et al., 1998; Merkle and Alvarez-Buylla, 2006), a protein also expressed by differentiated astrocytes. We did not observe coexpression of GFAP and $\beta$ T4 in vivo or in vitro. It may be, however, that $\beta \mathrm{T} 4$ and GFAP are expressed at different stages of stem cell activation or maturation. $\beta \mathrm{T} 4$ is the third cytoskeletal protein to be enriched in a distinct immature CNS cell population. $\beta 3$ tubulin is enriched in cells committed to the neuronal lineage (Lee et al., 1990; Menezes and Luskin, 1994), and GFAP- $\delta$ is an intermediate filament protein isoform detected in stem cells but not in astrocytes in which GFAP- $\alpha$ is expressed (Roelofs et al., 2005). However, no cell-specific function has been identified for these proteins, and their cytoplasmic distribution does not permit cell enrichment by panning or fluorescence-activated cell sorting. To date, no surface marker has been identified for the GFAP-positive stem cell. AC133 is a glycosylated epitope on human CD133/prominin-1 that has been used a marker for hematopoietic and cancer stem cells (Weigmann et al., 1997; Yin et al., 1997; Fargeas et al., 2007; Mizrak et al., 2008). In human tissue and rat neurospheres, $\beta$ T4 cells were not labeled by multiple commercially available antibodies to CD133 or prominin polypeptides. In addition, prominin-1 mRNA is not enriched in secondary versus primary neurospheres (R. Dutta, C. Wu, and B. D. Trapp, unpublished data). Therefore, we have no evidence for a relationship of $\beta$ T4 cells and either GFAP- or CD133-positive SVZ cells.

The developmental appearance of $\beta \mathrm{T} 4$ cells peaks during the latter stages of gliogenesis, which originate from the SVZ of the lateral ventricles. In vitro, $\beta \mathrm{T} 4$ cells are present in neurospheres generated from early postnatal SVZ but not from primary and secondary neurospheres produced from embryonic day 14 rat medial ganglionic eminence (data not shown), an early source of OPCs (Kessaris et al., 2006). In the human fetal brain, $\beta$ T4 cell density also peaks during the latter stage of gliogenesis, and $\beta \mathrm{T} 4$ cells are present at adult levels by the time most cerebral myelin has formed. It is possible, therefore, that a subpopulation of $\beta \mathrm{T} 4$ cells responsible for the latter stage of gliogenesis from the lateral ventricles remains in the SVZ of the adult brain, in which they are positioned to be activated in response to insults requiring new cell production.

One consistent observation in the adult CNS is that a variety of perturbations, including focal ischemia, contusion injuries, and demyelination, result in the mobilization of precursor or stem cells from localized origins (Iwai et al., 2006; Leker, 2006; Mazurová et al., 2006; Park et al., 2006; Nait-Oumesmar et al., 2007). When $\beta$ T4 cell densities are increased in SVZs bordering MS lesions, they often appear as doublets or in clusters, suggesting proliferation and symmetrical division of $\beta \mathrm{T} 4$ cells. We have not been able to detect the proliferation marker Ki-67 in $\beta$ T4 cells in control or MS tissue sections (data not shown). This may reflect intrinsically low rates of proliferation (in control brains) or tightly temporally defined proliferation periods (in MS brains), depending on mitogen availability. Indeed, $\beta \mathrm{T} 4$ cells in primary and secondary neurospheres had low rates of division in basal neurosphere medium.

Regardless of whether $\beta \mathrm{T} 4$ cells are true stem cells or primitive precursors, we propose that they represent a cellular source for the latter stages of CNS myelination and for neural repair in the adult CNS. The extensive myelination after transplantation of $\beta \mathrm{T} 4$ cells into the md rat and the increased density of SVZ $\beta \mathrm{T} 4$ cells bordering the lesions of MS support $\beta \mathrm{T} 4$ cell activation, proliferation, and differentiation in the setting of oligodendro- cyte deficiency and dysfunction. The potential of stem cell therapeutics to treat neurodegenerative diseases will require additional characterization of stem cells in human brain. We describe here an SVZ cell in the mammalian brain with accepted characteristics of stem cells. These include a low rate of proliferation, adhesion after enrichment, appropriate spatial, temporal, and quantitative distributions in developing and diseased human brain, and the ability to produce differentiated rat neural cells in vitro and in vivo. Additional studies, including the purification and expansion of human $\beta$ T 4 cells, are required before considering therapeutic applications for diseases of myelin.

\section{References}

Alvarez-Buylla A, Garcia-Verdugo JM (2002) Neurogenesis in adult subventricular zone. J Neurosci 22:629-634.

Barres BA, Raff MC (1994) Control of oligodendrocyte number in the developing rat optic nerve. Neuron 12:935-942.

Barres BA, Hart IK, Coles HS, Burne JF, Voyvodic JT, Richardson WD, Raff MC (1992) Cell death and control of cell survival in the oligodendrocyte lineage. Cell 70:31-46.

Belachew S, Chittajallu R, Aguirre AA, Yuan X, Kirby M, Anderson S, Gallo V (2003) Postnatal NG2 proteoglycan-expressing progenitor cells are intrinsically multipotent and generate functional neurons. J Cell Biol 161:169-186

Ben-Hur T, Rogister B, Murray K, Rougon G, Dubois-Dalcq M (1998) Growth and fate of PSA-NCAM+ precursors of the postnatal brain. J Neurosci 18:5777-5788.

Boison D, Stoffel W (1989) Myelin-deficient rat: a point mutation in exon III (A-C, Thr75-Pro) of the myelin proteolipid protein causes dysmyelination and oligodendrocyte death. EMBO J 8:3295-3302.

Bonfanti L (2006) PSA-NCAM in mammalian structural plasticity and neurogenesis. Prog Neurobiol 80:129-164.

Chang A, Nishiyama A, Peterson J, Prineas J, Trapp BD (2000) NG2positive oligodendrocyte progenitor cells in adult human brain and multiple sclerosis lesions. J Neurosci 20:6404-6412.

Chang A, Tourtellotte WW, Rudick R, Trapp BD (2002) Premyelinating oligodendrocytes in chronic lesions of multiple sclerosis. N Engl J Med 346:165-173.

Dentinger MP, Barron KD, Csiza CK (1982) Ultrastructure of the central nervous system in a myelin deficient rat. J Neurocytol 11:671-691.

Doetsch F, García-Verdugo JM, Alvarez-Buylla A (1997) Cellular composition and three-dimensional organization of the subventricular germinal zone in the adult mammalian brain. J Neurosci 17:5046-5061.

Doetsch F, Caillé I, Lim DA, García-Verdugo JM, Alvarez-Buylla A (1999) Subventricular zone astrocytes are neural stem cells in the adult mammalian brain. Cell 97:703-716.

Doetsch F, Petreanu L, Caille I, Garcia-Verdugo JM, Alvarez-Buylla A (2002) EGF converts transit-amplifying neurogenic precursors in the adult brain into multipotent stem cells. Neuron 36:1021-1034.

Fargeas CA, Huttner WB, Corbeil D (2007) Nomenclature of prominin-1 (CD133) splice variants: an update. Tissue Antigens 69:602-606.

Fiala JC (2005) Reconstruct: a free editor for serial section microscopy. J Microsc 218:52-61.

Ganat YM, Silbereis J, Cave C, Ngu H, Anderson GM, Ohkubo Y, Ment LR, Vaccarino FM (2006) Early postnatal astroglial cells produce multilineage precursors and neural stem cells in vivo. J Neurosci 26:8609-8621.

García-Verdugo JM, Doetsch F, Wichterle H, Lim DA, Alvarez-Buylla A (1998) Architecture and cell types of the adult subventricular zone: in search of the stem cells. J Neurobiol 36:234-248.

Goldman SA, Sim F (2005) Neural progenitor cells of the adult brain. Novartis Found Symp 265:66-80; discussion 82-97.

Grinspan JB, Franceschini B (1995) Platelet-derived growth factor is a survival factor for PSA-NCAM+ oligodendrocyte pre-progenitor cells. J Neurosci Res 41:540-551.

Inoue H, Ohsawa I, Murakami T, Kimura A, Hakamata Y, Sato Y, Kaneko T, Takahashi M, Okada T, Ozawa K, Francis J, Leone P, Kobayashi E (2005) Development of new inbred transgenic strains of rats with LacZ or GFP. Biochem Biophys Res Commun 329:288-295.

Iwai M, Ikeda T, Hayashi T, Sato K, Nagata T, Nagano I, Shoji M, Ikenoue T, Abe K (2006) Temporal profile of neural stem cell proliferation in the 
subventricular zone after ischemia/hypoxia in the neonatal rat brain. Neurol Res 28:461-468.

Joseph NM, Morrison SJ (2005) Toward an understanding of the physiological function of mammalian stem cells. Dev Cell 9:173-183.

Kessaris N, Fogarty M, Iannarelli P, Grist M, Wegner M, Richardson WD (2006) Competing waves of oligodendrocytes in the forebrain and postnatal elimination of an embryonic lineage. Nat Neurosci 9:173-179.

Kukekov VG, Laywell ED, Suslov O, Davies K, Scheffler B, Thomas LB, O’Brien TF, Kusakabe M, Steindler DA (1999) Multipotent stem/progenitor cells with similar properties arise from two neurogenic regions of adult human brain. Exp Neurol 156:333-344.

Learish RD, Brüstle O, Zhang SC, Duncan ID (1999) Intraventricular transplantation of oligodendrocyte progenitors into a fetal myelin mutant results in widespread formation of myelin. Ann Neurol 46:716-722.

Lee MK, Tuttle JB, Rebhun LI, Cleveland DW, Frankfurter A (1990) The expression and posttranslational modification of a neuron-specific betatubulin isotype during chick embryogenesis. Cell Motil Cytoskeleton 17:118-132.

Leker RR (2006) Manipulation of endogenous neural stem cells following ischemic brain injury. Pathophysiol Haemost Thromb 35:58-62.

Loeffler M, Roeder I (2002) Tissue stem cells: definition, plasticity, heterogeneity, self-organization and models - a conceptual approach. Cells Tissues Organs 171:8-26.

Lucchinetti C, Brück W, Parisi J, Scheithauer B, Rodriguez M, Lassmann H (1999) A quantitative analysis of oligodendrocytes in multiple sclerosis lesions. A study of 113 cases. Brain 122:2279-2295.

Mazurová Y, Rudolf E, Látr I, Osterreicher J (2006) Proliferation and differentiation of adult endogenous neural stem cells in response to neurodegenerative process within the striatum. Neurodegener Dis 3:12-18.

Menezes JR, Luskin MB (1994) Expression of neuron-specific tubulin defines a novel population in the proliferative layers of the developing telencephalon. J Neurosci 14:5399-5416.

Menn B, Garcia-Verdugo JM, Yaschine C, Gonzalez-Perez O, Rowitch D, Alvarez-Buylla A (2006) Origin of oligodendrocytes in the subventricular zone of the adult brain. J Neurosci 26:7907-7918.

Merkle FT, Alvarez-Buylla A (2006) Neural stem cells in mammalian development. Curr Opin Cell Biol 18:704-709.

Mizrak D, Brittan M, Alison MR (2008) CD133: molecule of the moment. J Pathol 214:3-9.

Nait-Oumesmar B, Picard-Riera N, Kerninon C, Decker L, Seilhean D, Höglinger GU, Hirsch EC, Reynolds R, Baron-Van Evercooren A (2007) Activation of the subventricular zone in multiple sclerosis: evidence for early glial progenitors. Proc Natl Acad Sci U S A 104:4694-4699.

Park KI, Hack MA, Ourednik J, Yandava B, Flax JD, Stieg PE, Gullans S, Jensen FE, Sidman RL, Ourednik V, Snyder EY (2006) Acute injury directs the migration, proliferation, and differentiation of solid organ stem cells: evidence from the effect of hypoxia-ischemia in the CNS on clonal "reporter" neural stem cells. Exp Neurol 199:156-178.

Reynolds BA, Rietze RL (2005) Neural stem cells and neurospheres: reevaluating the relationship. Nat Methods 2:333-336.

Reynolds BA, Weiss S (1992) Generation of neurons and astrocytes from isolated cells of the adult mammalian central nervous system. Science 255:1707-1710.

Roelofs RF, Fischer DF, Houtman SH, Sluijs JA, Van Haren W, Van Leeuwen FW, Hol EM (2005) Adult human subventricular, subgranular, and subpial zones contain astrocytes with a specialized intermediate filament cytoskeleton. Glia 52:289-300.

Roy NS, Benraiss A, Wang S, Fraser RA, Goodman R, Couldwell WT, Nedergaard M, Kawaguchi A, Okano H, Goldman SA (2000) Promotertargeted selection and isolation of neural progenitor cells from the adult human ventricular zone. J Neurosci Res 59:321-331.

Shamblott MJ, Axelman J, Wang S, Bugg EM, Littlefield JW, Donovan PJ, Blumenthal PD, Huggins GR, Gearhart JD (1998) Derivation of pluripotent stem cells from cultured human primordial germ cells. Proc Natl Acad Sci U S A 95:13726-13731.

Spassky N, Goujet-Zalc C, Parmantier E, Olivier C, Martinez S, Ivanova A, Ikenaka K, Macklin W, Cerruti I, Zalc B, Thomas JL (1998) Multiple restricted origin of oligodendrocytes. J Neurosci 18:8331-8343.

Temple S, Raff MC (1986) Clonal analysis of oligodendrocyte development in culture: evidence for a developmental clock that counts cell divisions. Cell 44:773-779.

Terada N, Kidd GJ, Kinter M, Bjartmar C, Moran-Jones K, Trapp BD (2005) $\mathrm{Beta}(\mathrm{IV})$ tubulin is selectively expressed by oligodendrocytes in the central nervous system. Glia 50:212-222.

Thomson JA, Itskovitz-Eldor J, Shapiro SS, Waknitz MA, Swiergiel JJ, Marshall VS, Jones JM (1998) Embryonic stem cell lines derived from human blastocysts. Science 282:1145-1147.

Trapp BD, Nishiyama A, Cheng D, Macklin W (1997) Differentiation and death of premyelinating oligodendrocytes in developing rodent brain. J Cell Biol 137:459-468.

Trapp BD, Peterson J, Ransohoff RM, Rudick R, Mörk S, Bö L (1998) Axonal transection in the lesions of multiple sclerosis. N Engl J Med 338:278-285

Weigmann A, Corbeil D, Hellwig A, Huttner WB (1997) Prominin, a novel microvilli-specific polytopic membrane protein of the apical surface of epithelial cells, is targeted to plasmalemmal protrusions of non-epithelial cells. Proc Natl Acad Sci U S A 94:12425-12430.

Wilson HC, Scolding NJ, Raine CS (2006) Co-expression of PDGF alpha receptor and NG2 by oligodendrocyte precursors in human CNS and multiple sclerosis lesions. J Neuroimmunol 176:162-173.

Windrem MS, Nunes MC, Rashbaum WK, Schwartz TH, Goodman RA, McKhann G 2nd, Roy NS, Goldman SA (2004) Fetal and adult human oligodendrocyte progenitor cell isolates myelinate the congenitally dysmyelinated brain. Nat Med 10:93-97.

Windrem MS, Schanz SJ, Guo M, Tian GF, Washco V, Stanwood N, Rasband M, Roy NS, Nedergaard M, Havton LA, Wang S, Goldman SA (2008) Neonatal chimerization with human glial progenitor cells can both remyelinate and rescue the otherwise lethally hypomyelinated shiverer mouse. Cell Stem Cell 2:553-565.

Wolswijk G (1998) Chronic stage multiple sclerosis lesions contain a relatively quiescent population of oligodendrocyte precursor cells. J Neurosci 18:601-609.

Woo K, Jensen-Smith HC, Ludueña RF, Hallworth R (2002) Differential synthesis of beta-tubulin isotypes in gerbil nasal epithelia. Cell Tissue Res 309:331-335.

Yin AH, Miraglia S, Zanjani ED, Almeida-Porada G, Ogawa M, Leary AG, Olweus J, Kearney J, Buck DW (1997) AC133, a novel marker for human hematopoietic stem and progenitor cells. Blood 90:5002-5012.

Yue T, Xian K, Hurlock E, Xin M, Kernie SG, Parada LF, Lu QR (2006) A critical role for dorsal progenitors in cortical myelination. J Neurosci 26:1275-1280. 